\title{
Turner Syndrome and Its Variants
}

\section{Turner Sendromu ve Varyantları}

\author{
Semra Gürsoy, Derya Erçal \\ Dokuz Eylül University Faculty of Medicine, Department of Pediatrics, Division of Pediatric Genetics, Izmir, Turkey
}

\begin{abstract}
Turner syndrome (TS) is a genetic disorder which is characterized by the complete or partial absence of the $X$ chromosome. The incidence is $1 / 2500$ female live births. The main clinical findings are short stature, primary amenorrhea and infertility, and phenotypical features include webbed neck, a low posterior hairline, cubitus valgus and shortening of the fourth metacarpal. While $1 \%$ of all still births have $45, X$ monosomy, this rate has been reported to be approximately $10 \%$ in spontaneous abortions. The karyotype is determined as $45, X$ in about half of the patients. Therefore, most of the TS fetuses are considered to end in spontaneous abortion and only mosaic cases survive to term. Isochromosome $\mathrm{Xq}$ is the most common structural rearrangement of the $X$ chromosome. Furthermore, ring $X$ chromosome, deletions and $Y$ chromosome abnormalities can be detected in patients with TS.

Keywords: Turner syndrome, mosaicism, isochromosome, ring chromosome, short stature
\end{abstract}

\section{$0 \ddot{Z}$}

Turner sendromu (TS), X kromozomunun tamamen ya da parsiyel olarak yokluğu sonucu oluşan genetik bir bozukluktur. Canlı doğan kız çocuklarındaki sıkık 1/2500 olarak bildirilmektedir. Kısa boy, primer amenore ve infertilite gibi klinik bulgularla birlikte hastalarda boyunda yelelenme, düşük ense saç çizgisi, kubitus valgus, kısa 4. metakarpal kemik gibi fenotipik özellikler görülebilir. Ölü doğumların \%1'inde 45,X monozomisi saptanırken, bu oran spontan düşüklerde yaklaşık olarak \%10 olarak bildirilmektedir. Hastaların \%50'sinde karyotip 45,X monozomisi şeklindedir. Ancak bu karyotipe sahip TS'li olguların çoğu fetal dönemde spontan düşükle sonlanmakta olup hayatta kalanların ise mozaik oldukları düşünülmektedir. En sık görülen yapısal $X$ kromozomu anomalisi ise izokromozom $X q^{\prime}$ dur. Ayrica halka kromozom, delesyonlar gibi $X$ kromozomunun yapısal anomalileri ile birlikte hastalarda $Y$ kromozomuna ait patolojiler de saptanabilir.

Anahtar Kelimeler: Turner sendromu, mozaiklik, izokromozom, halka kromozom, kısa boy

\section{Introduction}

Turner syndrome (TS) is a genetic disorder that was first described by Turner (1) in 1938, and is the result of the complete or partial absence of the $\mathrm{X}$ chromosome.

TS is one of the most common chromosomal abnormalities among female live births with an estimated frequency of $1 / 2500$ (2). Clinical findings include short stature, primary amenorrhea, infertility and characteristic stigmatas. The phenotypic features are low nuchal hair line, low-set ears, small mandibula, cubitus valgus, nail hypoplasia, high palate, swelling of the hands and feet in the neonatal period, short $4^{\text {th }}$ metacarpal bone, discrete nipples and wide thoracic cage. Cardiac and renal anomalies, hypothyroidism, hearing and vision disorders, gastrointestinal and dermatological problems and neoplasms may also been seen in TS (3). Although some of the patients may be diagnosed at birth due to the presence of dysmorphic findings, diagnosis is delayed until childhood, adolescence or later. Intelligence is generally not affected. However, learning difficulties that affect nonverbal, perceptual, motor and visuo-spatial skills can be seen in $70 \%$ of the patients (4). In a recent study the authors compared TS patients with healthy individuals and suggested that verbal and nonverbal cognitive impairment may be due to anomalies in gray matter development (5).

\section{Address for Correspondence/Yazışma Adresi}

Semra Gürsoy MD, Dokuz Eylül University Faculty of Medicine, Department of Pediatrics, Division of Pediatric Genetics, Izmir, Turkey

Phone: +90 5063672451 E-mail: dr.semra@hotmail.com ORCID ID: orcid.org/0000-0002-6795-3012

Received/Geliş tarihi: 21.11.2015 Accepted/Kabul tarihi: 21.12.2015

๑ Copyright 2017 by Ege University Faculty of Medicine, Department of Pediatrics and Ege Children's Foundation 
Approximately $50 \%$ of TS patients have $45, X$ karyotype and the most common structural $X$ chromosome abnormality is isochromosome $\mathrm{Xq}$. The retained $\mathrm{X}$ chromosome is maternally derived in two thirds of the patients. The patients with 46,XY cell line mosaicism or structural rearrangement of the $Y$ chromosome mostly have masculinized external genitalia and are at increased risk of developing gonadoblastoma and other gonadal tumors, whereas patients with mosaic 46,XX karyotype or isochromosome Xq have a milder phenotype (6).

TS with $45, X$ karyotype has been observed in $1-2 \%$ of human conceptions, $10 \%$ of first trimester pregnancy losses and $1 \%$ of stillbirths. More than $99 \%$ of $45, X$ fetuses end with abortion, typically by the 28th week of gestation, which suggests that living $45, X$ individuals must have mosaicism for another cell line $(7,8)$. The etiology includes pre and postconceptional errors, as well as meiotic non-disjunction and anafase lag.

The pseudoautosomal regions (PAR) of $X$ and $Y$ chromosomes are both necessary for normal development. It has been reported that haplo-insufficiency in the CSF2RA gene located in the PAR1 region, which plays a role in normal placental development, is responsible for high mortality in $45, X$ karyotype embryos $(9,10)$. Recently, it has been suggested that all living patients in whom TS with $45, X$ karyotype has been diagnosed, are cryptic mosaics. Loss of $X$ chromosome in these embryos frequently result in mitotic error, but it has been reported that this loss may occur at various stages of postfertilization (11).

The diagnosis is made by karyotype analysis of peripheral blood which shows the numerical and/or structural abnormalities of the $X$ chromosome. However, mosaicism can be better defined in approximately $30 \%$ of non-mosaic patients by increasing the number of cells examined in the karyotype analysis, evaluating additional tissue samples or using fluorescence in situ hybridization method (12). In this review, we aimed to evaluate the phenotypical characteristics, clinical variability and the responsible genes of TS and its variants, and provide a general approach to patients with suspected TS.

\section{Turner Syndrome with Structural Abnormalities of the X Chromosome}

\section{Isochromosome $X[46, X, i(X)]$}

Isochromosome is a structural chromosomal aberration consisting of two short arms or two long arms, which are derived by centromere division. The most common structural abnormality of $X$ chromosome is $46, X, i(X q)$. The frequency of isochromosome was reported to be $15-18 \%$ in TS cases with or without mosaicism (13). Short stature, which is one of the most frequently observed clinical features, can be explained by SHOX haplo-insufficiency (14). Therefore, while short stature is more frequently present in patients with $46, \mathrm{X}, \mathrm{i}(\mathrm{Xq})$ karyotype, gonadal dysfunction is more likely to be seen in patients with $46, X, i(X p)$ karyotype, which is a very rare entity.
The incidence of autoimmune thyroid disease in TS increases with advanced age. Recently, a twofold increase in the prevalence of autoimmune thyroid disease has been observed from the first to the third decade of life in patients with the isochromosome karyotype (15). In addition, patients with $45, X$ or $46, X, i(X q)$ karyotype carry a higher risk of developing hearing loss when compared to patients with mosaic karyotypes. A linear relationship was also found between age and hearing loss (16).

\section{Ring Chromosome [46,X,r(X)]}

Ring chromosomes usually result from two terminal breaks in both chromosome arms, followed by the fusion of the broken ends. The ascentric part often disappeares and partial monosomy occurs. Ring chromosomes cause complex mitotic events. The phenotype is highly variable according to the size of ring chromosome and the deletions of short and long arms. A ring $X$ chromosome is found in approximately $6 \%$ of the patients with TS, generally with mosaicism for a $45, X$ cell line (4).

Females with $46, X, r(X)$ karyotype may have typical TS findings such as short stature, peripheral edema, characteristic facial features, low neck hairline, ovarian dysgenesis, and endocrine disorders. On the other hand, mental retardation, learning disability, autism spectrum disorders, and structural brain abnormalities are more frequently observed in TS with ring chromosome than TS with 45,X karyotype. Some patients may have more severe phenotypical features and this is thought to be related to whether the $X$ inactivation center is functional or not (17).

In normal females one of the two $X$ chromosomes becomes inactive in the early stages of life and the expression of the X-linked genes is equalized for both sexes. The inactivation of an $X$ chromosome is random, which is maintained in a clonal manner throughout subsequent cell divisions. As a result, females become mosaic in terms of gene expression associated with the $X$ chromosome (18).

$X$ inactivation center, which plays an important role in the expression of the $X$-inactive specific transcript (XIST) gene, is localized on the $X$ chromosome at position q13. Also, XIST gene appears to be a key master regulatory locus for $X$ inactivation. In patients with structural abnormalities of the $X$ chromosome, the abnormal $X$ chromosome (such as deletions, duplications, isochromosomes) is always the one inactivated. Smaller ring chromosomes may lack the XIST locus, rendering them functionally disomic for the genes present on the ring. Females with mosaic ring $X$ chromosome without XIST expression can also have extremity anomalies, abnormal pigmentation and facial features of Kabuki make-up syndrome in addition to mental retardation $(18,19)$. Hyperinsulinemic hypoglycemia is an atypical feature which can be seen especially in patients with mosaic karyotype (20).

\section{Deletion (Xp or Xq)}

The frequency of $\mathrm{Xp}$ deletion in patients with TS is approximately $2 \%$ (4). Short stature, gonadal dysgenesis 
and characteristic TS stigmatas are especially observed in patients who show deletion of the entire short arm. Furthermore, the phenotype is variable in partial deletions.

The region Xp22.33-Xp22.12 contains the SHOX gene, which is located in the terminal region. The gene escapes from $X$ inactivation, and its function is dosage dependent. Therefore, haplo-insufficiency of SHOX gene causes growth retardation (21). The SHOX gene is expressed in the pharyngeal arch, limbs, osteogenic cells, bone marrow, and fibroblasts. As well as short stature, skeletal abnormalities including short metacarpals, high palate, cubitus valgus, Madelung deformity, and mesomelic dysplasia may also be seen in the haplo-insufficiency of the gene. (22). Mutations involving the SHOX gene or its regulatory regions can be detected in approximately $17 \%$ of the patients with idiopathic short stature, and in $50-90 \%$ of the patients with Leri-Weill syndrome (23).

The genes located on Xp and Yp are necessary for normal development of the cardiovascular system. Congenital heart diseases have an important role in prenatal and postnatal mortality in patients with TS. The most common cardiovascular defects are bicuspid aortic valve (30\%) and aortic coarctation (12\%). Additionally, hypoplastic left heart syndrome, usually lethal, is seen in about $10 \%$ of the patients $(24,25)$. In particular, left ventricular outflow tract defects are associated with the terminal region of Xp.

The cytogenetic studies have shown that the region between $\mathrm{Xq13}$ and $\mathrm{Xq28}$ is important for normal ovarian function. The $X q 13-q 21$ region is defined as the critical region (CR) 1, and the proximal deletions of this region are usually compatible with normal menstruation and fertility. The terminal and interstitial deletions of the CR2 at Xq23-q28 are mostly responsible for premature ovarian failure (26). The FMR1 gene, which is important in the ovarian function, is localized in the Xq27.3 locus, and expansions in the exon 1 triplet repeat of the gene are associated with an increased risk of early menopause (27).

\section{Turner Syndrome with Mosaicism}

Although classic TS karyotype is $45, \mathrm{X}, 30-40 \%$ of the remaining have a mosaic pattern with a second cell line $(45, X / 46, X X, 45, X / 47, X X X, 45, X / 46, X Y, 45, X / 47, X Y Y$ and $46, X$, delXq) $(4,28)$.

\section{$45, X / 46, X X$}

The most common form of mosaicism is $45, \mathrm{X} / 46, \mathrm{XX}$ $(15 \%)$ which includes both the cell line with the normal karyotype and the pathological cytogenetic structure (29). These patients may have a normal phenotype rather than typical TS features. However, spontaneous menstruation occurs in about $3 \%$ of the $45, \mathrm{X}$ females, and up to $20 \%$ of mosaic females. While the mean adult length is higher in mosaic females, the probability of the presence of a somatic anomaly is lower.
Psychiatric disorders can also be seen. Especially, the majority of TS patients with schizophrenia had a mosaic $45, X / 46, X X$ karyotype. It has been suggested that the potential of gene dose-effect might be associated with the abnormal expression of an $\mathrm{X}$ chromosome gene product which has a susceptibility for schizophrenia in TS (30). Recently, it has been suggested that the HOPA gene which is located on Xq13, might be involved in the development of schizophrenia as well as being associated with mental retardation and thyroid dysfunction (31).

\section{$45, X / 46, X Y$}

TS with $46, X Y$ cell line can be seen in $5-10 \%$ of the patients (32). Its clinical features are quite variable. The patients may have typical TS phenotype, normal male appearance, moderate masculinization, male pseudohermaphroditism, and mixed gonadal dysgenesis which can be transformed into a malignant form (33). However, the presence of $Y$ cell line can not be predicted from the phenotype. Patients with a normal female phenotype without evidence of masculinization may also have a 46,XY cell line. Therefore, the patients should be closely followed-up due to the risk of any germ cell tumor, especially gonadoblastoma. In current literature, the frequency of developing germ cell tumor is reported to be about $15 \%$ in patients with $45, X / 46, X Y$ karyotype (32).

\section{$45, X / 47, X X X$}

Triple $X$ syndrome occurs at a frequency of $1 / 1000$ in live-born females. Clinical features include long stature with large hands/feet and microcephalic appearance, hypotonia, seizures, genitourinary abnormalities, and premature ovarian failure. Onset of puberty, sexual development, and fertility are usually normal. Speech and motor retardation, learning disability, attention deficit and behavioral disorders may be seen also in patients with 47,XXX karyotype (34).

The $45, X / 47, X X X$ karyotype, which is extremely rare, constitutes $3-4 \%$ of the patients with TS and the etiology can be attributed to post-zygotic non-dysjunction that occurs in the normal disomic cell lines. The patients usually have a milder phenotype and the characteristic stigmatas of TS may not be seen. Ovarian failure may be observed however, and spontaneous menarche and fertility are more common in patients with $45, X / 47, X X X$ karyotype than those with monosomy (35). Previous studies reported the frequency of spontaneous menarche and fertility as $84 \%$ and $69 \%$ respectively in patients with 45,X/47,XXX karyotype (36). Morever, there was no significant difference between the patients with 45,X karyotype and those with 45,X/47,XXX and $45, X / 46, X X / 47, X X X$ karyotype with regard to the development of mental retardation. However, cell counts that provide a ratio of $45, X$ to $47, X X X$ cells should not be considered to have predictive value, because they vary in different tissues $(36,37)$

In conclusion, TS is a complex, reproductive and developmental disorder. Because the clinical features are 
quite variable, the phenotype-genotype correlation may not always be achieved. For this reason, karyotype analysis should be done in patients with a clinical suspicion of TS, even in the absence of the phenotypic stigmatas, and the probability of a mosaic karyotype should be kept in mind. Early diagnosis will improve the life quality of these patients and could prevent future problems that may arise during adulthood.

\section{Ethics}

Peer-review: Internally peer-reviewed.

\section{Authorship Contributions}

Surgical and Medical Practices: S.G., D.E., Concept: D.E., Design: D.E., Data Collection or Processing: S.G., Analysis or Interpretation: S.G., D.E., Literature Search: S.G., Writing: S.G., D.E.

Conflict of Interest: No conflict of interest was declared by the authors.

Financial Disclosure: The authors declared that this study has received no financial support.

\section{References}

1. Turner $\mathrm{HH}$. A syndrome of infantilism, congenital webbed neck, and cubitus valgus. Endocrinology 1938;23:566-74.

2. Nielsen J, Wohlert M. Chromosome abnormalities found among 34,910 newborn children: results from a 13-year incidence study in Arhus, Denmark. Hum Genet 1991;87:81-3.

3. Homer L, Le Martelot MT, Morel F, et al. 45,X/46,XX mosaicism below $30 \%$ of aneuploidy: clinical implications in adult women from a reproductive medicine unit. Eur J Endocrinol 2010;162:617-23.

4. Sybert VP, Mccauley E. Turner's syndrome. N Engl J Med 2004;351:1227-38

5. Zhao Q, Zhang Z, Xie S, et al. Cognitive impairment and gray/white matter volume abnormalities in pediatric patients with Turner syndrome presenting with various karyotypes. J Pediatr Endocrinol Metab 2013;26:1111-21.

6. Al Alwan I, M K, Amir, et al. Turner Syndrome Genotype and phenotype and their effect on presenting features and timing of Diagnosis. Int J Health Sci (Qassim) 2014;8:195202.

7. Hook EB, Warburton D. The distribution of chromosomal genotypes associated withTurner's syndrome: livebirth prevalence rates and evidence for diminished fetal mortality and severity in genotypes associated with structural $X$ abnormalities or mosaicism. Hum Genet 1983;64:24-7.

8. Held KR, Kerber S, Kaminsky E, et al. Mosaicism in 45,X Turner syndrome: does survival in early pregnancy depend on the presence of two sex chromosomes? Hum Genet 1992;88:288-94.

9. Urbach A, Benevisty N. Studying early lethality of $45, X O$ (Turner's syndrome) embryos using human embryonic stem cells. PLoS One 2009;4:e4175.

10. Migeon BR. Females are mosaics: X-inactivation and sex differences in disease. Oxford University Press: Oxford, 2014.
11. Hook EB, Warburton D. Turner syndrome revisited: review of new data supports the hypothesis that all viable $45, X$ cases are cryptic mosaics with a rescue cell line, implying an origin by mitotic loss. Hum Genet 2014;133:417-24.

12. Freriks K, Timmers HJ, Netea-Maier RT, et al. Buccal cell FISH and blood PCR-Y detect high rates of $X$ chromosomal mosaicism and $Y$ chromosomal derivatives in patients with Turner syndrome. Eur J Med Genet 2013;56:497-501.

13. Wolff DJ, Van Dyke DL, Powell CM; Working Group of the ACMG Laboratory Quality Assurance Committee. Laboratory guideline for Turner syndrome. Genet Med 2010;12:52-5.

14. Cuesta Hernández M, Rueda Valencia ME, Pérez Rodríguez O, López de Lara D. [X isochromosomes: delayed diagnosis of Turner's syndrome]. An Pediatr (Barc) 2015;82:131-4.

15. De Kerdanet M, Lucas J, Lemee F, Lecornu M. Turner's syndrome with X-isochromosome and Hashimoto's thyroiditis. Clin Endocrinol (Oxf) 1994;41:673-6.

16. Oliveira CS, Ribeiro FM, Lago R, Alves C. Audiological abnormalities in patients with Turner syndrome. Am J Audiol 2013;22:226-32.

17. Lepping KA, Sybert VP, Ross JL, et al. Phenotype and $X$ inactivation in $45, X / 46, X, r(X)$ cases. Am J Med Genet 2004;3:276-84.

18. Nussbaum RL, Mclnnes RR, Willard HF Thompson \& Thompson Genetics in Medicine. 7th ed. Philadelphia, Saunders, 2007.

19. Tomkins DJ, McDonald HL, Farrell SA, Brown CJ. Lack of expression of XIST from a small ring $X$ chromosome containing the XIST locus in a girl with short stature, facial dysmorphism and developmental delay. Eur J Hum Genet 2002;10:44-51.

20. Cappella M, Graziani V, Pragliola A, et al. Hyperinsulinemic Hypoglycaemia in a Turner Syndrome with Ring (X). Case Rep Pediatr 2015;2015:561974.

21. ChoSY, Ki CS, Jang JH, et al. Familial Xp22.33-Xp22.12 deletion delineated by chromosomal microarray analysis causes proportionate short stature. Am J Med Genet A 2012;158:1462-6

22. Seo GH, Kang E, Cho JH, et al. Turner syndrome presented with tall stature due to over dosage of the SHOX gene. Ann Pediatr Endocrinol Metab 2015;20:110-3.

23. Child CJ, Kalifa G, Jones $C$, et al. Radiological Features in Patients with Short Stature Homeobox-Containing (SHOX) Gene Deficiency and Turner Syndrome before and after 2 Years of GH Treatment. Horm Res Paediatr 2015;84:14-25.

24. Ho VB, Bakalov VK, Cooley $M$, et al. Major vascular anomalies in Turner syndrome: prevalence and magnetic resonance angiographic features. Circulation 2004;110:1694700.

25. Sachdev V, Matura L, Sidenko S, et al. Aortic valve disease in Turner syndrome. J Am Coll Cardiol 2008;51:1904-9.

26. Mercer CL, Lachlan K, Karcanias A, et al. Detailed clinical and molecular study of 20 females with $\mathrm{Xq}$ deletions with special reference to menstruation and fertility. Eur J Med Genet 2013;56:1-6.

27. Murray A. Premature ovarian failure and the FMR1 gene. Semin Reprod Med 2000;18:59-66.

28. Ranke MB, Saenger P. Turner's syndrome. Lancet 2001;358:309-14. 
29. Rapaport R. Hypofunction of theOvaries. In: Kliegman RM, Behrman RE, Jenson HB, Stanton BF, (eds). Nelson Textbook of Pediatrics. 18th ed. Philadephia, Saunders, 2008;2316-40.

30. Prior TI, Chue PS, Tibbo P. Investigation of Turner syndrome in schizophrenia. Am J Med Genet 2000;96:373-8.

31. Jung SY, Park JW, Kim DH, Jun YH, Lee JS, Lee JE. Mosaic Turner syndrome associated with schizophrenia. Ann Pediatr Endocrinol Metab 2014;19:42-4.

32. Cools M, Drop SL, Wolffenbuttel KP, Oosterhuis JW Looijenga LH. Germ cell tumors in the intersex gonad: old paths, new directions, moving frontiers. Endocr Rev 2006;27:468-84.
33. Hennekam RCM, Krantz ID, Allanson JE. "Turner syndrome", in Gorlin's syndromes of the head and neck. Oxford, Oxford University Press, 2010.

34. Tartaglia NR, Howell S, Sutherland A, Wilson R, Wilson L.A review of trisomy X (47,XXX). Orphanet J Rare Dis 2010;5:8.

35. Maciejewska-Jeske M, Czyzyk A, Meczekalski B. The Turner syndrome in patient with 45X/47XXX mosaic karyotype case report. Gynecol Endocrinol 2015;31:526-8.

36. Sybert VP. Phenotypic effects of mosaicism for a $47, X X X$ cell line in Turner syndrome. J Med Genet 2002;39:217-20.

37. Everest E, Tsilianidis LA, Haider A, Rogers DG, Raissouni N, Schweiger B. 45,X/47, XXX Mosaicism and Short Stature. Case Rep Pediatr 2015;2015:263253. 